\title{
Parameterisasi Proses Buffer Pada Pengolahan Data Spasial untuk Identifikasi Zonasi Penerimaan Siswa SMA Terhadap Lulusan SMP di Pulau Lombok
}

\author{
Buffer Process Parameterization In Spatial Data \\ Processing to Identification of Zoning SMA's \\ Admissions For SMP Graduates On Lombok Island
}

\author{
Agus Pribadi ${ }^{1}$ \\ ${ }^{1}$ Universitas Bumigora \\ Adi_ms2003@yahoo.com ${ }^{1 *}$
}

Submitted: 11 Desember 2021, Revised: 14 Desember 2021, Accepted: 29 Desember 2021

\begin{abstract}
Abstrak - Pemerintah telah menyusun kebijakan program wajib belajar (Wajar) menjadi 12 tahun. Berdasarkan program Wajar 12 tahun, maka pihak pemangku kepentingan, Dinas Pendidikan serta pihak sekolah menengah perlu melakukan identifikasi untuk memastikan bahwa seluruh lulusan SMP dapat diterima di SMA. Untuk mendapatkan identifikasi zonasi diperlukan informasi spasial yang dapat mengilustrasikan zonasi SMA untuk penerimaan peserta didik baru. Identifikasi tersebut diperlukan untuk mengetahui lebih awal kemungkinan terdapatnya wilayah yang di luar jangkauan zonasi SMA ataupun mencegah penumpukan yang berada di satu sekolah menengah. Identifikasi zonasi SMA maupun SMP, memperlukan proses buffer data spasial. Proses buffer dapat dilaksanakan jika tersedia nilai jarak guna membentuk area zonasi. Nilai jarak diperoleh menggunakan parameterisasi untuk menentukan nilai jarak dalam proses buffer. Parameterisasi disusun dengan tahapan, penyiapan dan integrasi data spasial, penyusunan parameter, dan proses verifikasi parameter sampai valid. Parameter yang diperoleh pada formulasi digunakan untuk mendapatkan nilai jarak yang dibutuhkan dalam proses buffer data spasial. Mencapai 90\%. zonasi wilayah SMA diperoleh melalui proses buffer yang nilainya diperoleh berdasarkan parameter yang telah disusun. Dapat disimpulkan, parameterisasi proses buffer dalam pengolahan data spasial untuk mengidentifikasi zonasi penerimaan siswa SMA terhadap lulusan SMP di pulau Lombok, dapat tercapai.
\end{abstract}

Kata Kunci: buffer, data spasial, zonasi.

\begin{abstract}
The government has compiled a compulsory education program (Wajar) to be 12 years. Local agency of Education and Senior high schools need to identify to ensure that all junior high school graduates can be accepted into senior high school. To obtain zoning identification, spatial information is needed that can illustrate the high school zoning for the acceptance of new students. This identification is needed to find out in advance the possibility of the presence of areas outside the reach of high school zoning or to prevent accumulation in a senior high school. Identification of SMA and SMP zoning requires a spatial data buffer process. The buffer process can be carried out if a distance value is available. $90 \%$ of the distance value can be obtained using parameterization to specify the distance value in the buffer process. Parameterization is arranged in stages, preparation and integration of spatial data, formula/parameter composing, and parameter verification process until it is valid. Parameter obtained in the formulation used to get the required distance value in the spatial data buffer process. $90 \%$ of SMA zoning area can be obtained through a buffer process whose values are obtained based on the parameter that has been compiled. Conclusion is the parameterization of the buffer process in spatial data processing to identify the zoning of admissions for high school students based on junior high school graduates on the Lombok island proven.
\end{abstract}

Keywords: buffer, zonation, spatial data.

Jurnal Bumigora Information Technology (BITe)

Vol.3, No.2, Desember 2021, pp. 175-184

ISSN: 2685-4066

175

DOI: 10.30812/bite.v3i2.1607 


\section{Pendahuluan}

Satuan pendidikan di Indonesia berdasar jenjang meliputi pendidikan dasar, menengah dan tinggi [1]. Berdasar perundangan tersebut, jenjang pendidikan dasar meliputi Sekolah Dasar (SD), Madrasah Ibtidaiyah (MI), Sekolah Menengah Pertama (SMP) dan Madrasah Tsanawiyah MTs). Jenjang pendidikan menengah yang dimaksud perundangan tersebut meliputi Sekolah Menengah Atas (SMA), Madrasah Aliyah (MA), Sekolah Menengah Kejuruan (SMK) dan Madrasah Aliyah Kejuruan (MAK). Pemerintah telah menyusun kebijakan program wajib belajar (Wajar) menjadi 12 tahun [2]. Program tersebut dipilih dalam rangka upaya Pemerintah melalui Kementrian Pendidikan dan Kebudayaan untuk meningkatkan sumber daya manusia (SDM). Berdasar Undang-undang nomor 20 tahun 2003, bahwa pendidikan menengah merupakan kelanjutan dari pendidikan dasar [3].

Memahami penjenjangan pendidikan di Indonesia, pendidikan menengah (SMA, SMK, MA dan MAK) dapat dipahami merupakan jenjang pendidikan yang memberikan pembekalan keterampilan hidup maupun penyiapan secara social [2]. Merujuk pada program pendidikan nasional berupa Wajar 12 tahun, ketersediaa jenjang sekolah menengah sangat perlu dan penting guna membentuk generasi yang siap [4]. Ketersediaan fasilitas sekolah di pulau Lombok tidak cukup berimbang. Menurut data yang pernah terpresentasikan, di kabupaten Lombok Barat memiliki 55 SMP dan tersedia 54 SMA, namun di kabupaten Lombok Tengah terdapat 410 SMP namun hanya 133 SMA [5]. Menurut hasil pemetaan sekolah, daerah kabupaten Lombok Timur dan kabupaten Lombok Tengah didapati rawan ketersediaan fasilitas SMA, karena jumlah, komposisi dan ketersediaan berdasar lokasi [4] Berdasar contoh kasus tersebut, ketersediaan fasilitas satuan pendidikan jenjang SMA komposisinya belum berimbang dengan adanya fasilitas satuan pendidikan jenjang SMP pada suatu wilayah tertentu di pulau Lombok.

Menurut Peraturan Menteri Pendidikan dan Kebudayaan nomor 14 tahun 2018, penerimaan calon peserta didik menggunakan sistem zonasi [6]. Sistem zonasi tersebut menggunakan pola area berdasar suatu jarak tertentu untuk menentukan wilayah / zona yang menjadi asal / tempat tinggal calon peserta didik suatu sekolah, dalam bahasan ini sekolah menengah. Secara fakta di lapangan, ukuran jarak tidak mudah didefinisikan karena memiliki keadaan atau faktor yang beragam dan tidak sama di tiap wilayah atau kondisi sekitar sekolah [7]. Pengelolaan penampungan calon siswa sekolah menengah diberikan kepada pemangku kepentingan bidang pendidikan di tiap daerah, yaitu Dinas Pendidikan setempat. Sesuai Peraturan Menteri Pendidikan dan Kebudayaan nomor 14 tahun 2018, pelaksanaan sistem zonasi dibantu dengan mekanisme penyeimbangan distribusi yang dikelola oleh Dinas Pendidikan [7]. Pelaksnaan peraturan yang ditunjang dengan dukungan teknis pengelolaan distribusi lokasi calon siswa diperlukan untuk memastikan tidak adanya ketimpangan distribusi asal siswa terhadap sekolahnya. Memperhatikan data jumlah SMP dan SMA, maka terdapat kesenjangan antara jumlah lulusan SMP dan ketersediaan SMA yang menampung. Berdasar regulasi, maka dimungkinkan tidak semua lulusan SMP akan langsung tertampung di SMA.

Permasalahan yang mengemuka adalah bagaimana mengidentifikasi zonasi SMA untuk penampungan lulusan SMP. Zonasi penerimaan peserta didik baru SMA memiliki kesamaan teknis dengan luasan buffer dalam pemrosesan data spasial, dan memerlukan komponen jarak untuk membentuknya [8]. Idendifikasi kapasitas sekolah menengah terhadap penampungan lulusan SMP diperlukan untuk mekanisme kontrol dan pengelolaan distribusi siswa terhadap sekolahnya berdasarkan zona yang sesuai.

Parameterisasi proses buffer pada pengolah data spasial sekolah merupakan salah satu alternatif yang dapat dipergunakan untuk identifikasi atau pendugaan area zonasi. Diperolehnya area zonasi dapat digunakan sebagai langkah identifikasi kapasitas calon siswa yang akan ditampung oleh suatu fasilitas sekolah menengah terhadap lulusan jenjang sekolah dasar (SMP). Parameterisasi proses buffer data spasial sekolah ini akan membantu pihak Dinas Pendidikan dalam mengelola, mengontrol dan mengatur pelaksanaan zonasi penerimaan siswa baru sekolah menengah. Diperolehnya hasil olah spasial menggunakan proses buffering ini akan membantu 
dalam identifikasi pendugaan daya tamping fasilitas sekolah menengah dalam menampung lulusan SMP.

\section{Metodologi}

Pembahasan parameterisasi proses buffer pada pengolahan data spasial untuk identifikasi zonasi penerimaan siswa SMA terhadap lulusan SMP ini memiliki potensi terhadap pendugaan kapasitas calon siswa sekolah menengah yang harus diterma. Bahasan parameterisasi proses buffer pada pengolahan data spasial dalam artikel ini dibatasi hanya SMA terhadap lulusan SMP di pulau Lombok. Pembatasan bahasan ini untuk keperluan studi awal serta untuk mengetahui potensi dasar parameterisasi proses buffer pengolahan data spasial untuk keperluan identifikasi. SMA dan SMP yang dipergunakan sebagai sample bahasan terbatas pada sekolah kategori favorit dan berada di akses jalan utama.

Metodologi yang dipergunakan dalam bahasan parameterisasi proses buffer sesuai ilustrasi pada Gambar 1. Pada Gambar 1 menyajikan tahapan dan faktor penyerta yang menjadi penyerta dalam tiap tahapan.

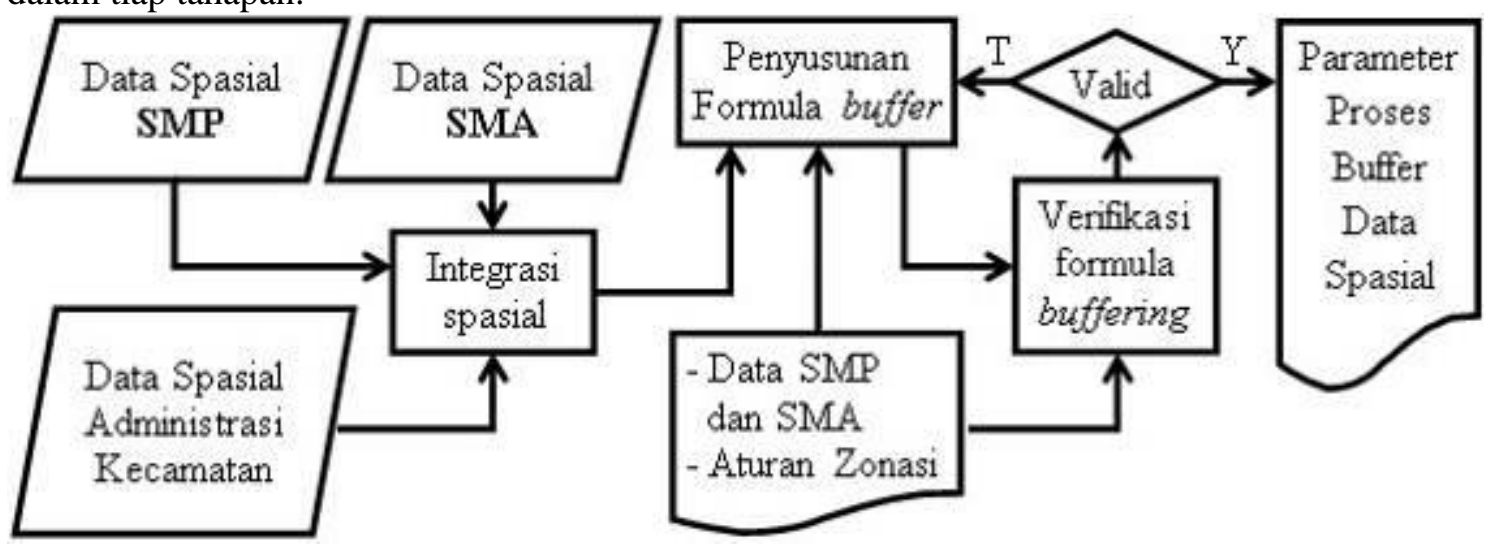

Gambar 1. Metodologi

Secara garis besar, tahapan dalam metode penelitian merupakan perpaduan antara mekanisme tahapan pemodelan dan perosesan data spasial.

\subsection{Integrasi Spasial}

Proses integrasi data spasial tema SMP dan SMA dengan tema administrasi wilayah merupakan tahapan awal yang penting. Mekanisme ini diterapkan karena diperlukan peninjauan lokasi berdasar wilayah administrasi lokasi tiap sekolah dalam proses spasialnya. Proses integrasi ini pada dasarnya adalah pemrosesan data spasial awal sebelum diberlakukan proses buffer untuk mengetahui zonasi terhadap lokasi fasilitas sekolah menengah. Pengolahan data spasial pada tahap ini merupakan pre-processing untuk pengolahan akhir berupa proses buffer untuk mendapatkan zonasi [9].

Data sasial yang dipergunakan dalam tahapan pre-processing adalah data spasial administrasi berbasis wilayah Kecamatan, data spasial lokasi SMP dan data spasial lokasi SMA. Tahapan pre-processing diperlukan dalam tiap pengolahan atau pemrosesan data spasial untuk menghasilkan produk informasi spasial [9]. Masing-masing data spasial sekolah akan dipergunakan sebagai bahan untuk pemrosesan spasial guna mendapatkan zona wilayah SMA.

\subsection{Penyusunan Formula Buffer}

Tahap penyusunan formula didasarkan pada referensi spasial dan merujuk pada data pokok tentang keberadaan sekolah, kapasitas dan kapabilitas sekolah. Penyusunan juga didasarkan pada peraturan zonasi penerimaan peserta didik baru pada satuan pendidikan sekolah menengah SMA [7].

Pada tahap ini dilakukan proses analisa spasial terhadap data lokasi sekolah dan diolah bersama dengan data (atribut) satuan pendidikan, SMP dan SMA. Proses formulasi ini 
mengahasilkan parameter mendapatkan value yang diimplementasikan pada proses buffer terhadap data spasial lokasi SMA. Proses buffer terhadap data spasial lokasi SMA menggunakan value yang berdasarkan data pada atributnya [10].

\subsection{Verifikasi Formula Buffer}

Tahap verifikasi ini dipergunakan untuk menguji parameter yang dihasilkan oleh tahap penyusunan. Dalam verifikasi ini menggunakan model pemrosesan data spasial yang telah tersusun berdasar hasl penelitian pendahuluan dan telah didaftarkan sebagai ciptaan [11]. Gambar 2 adalah model pengolahan data spasial yang dimaksud.

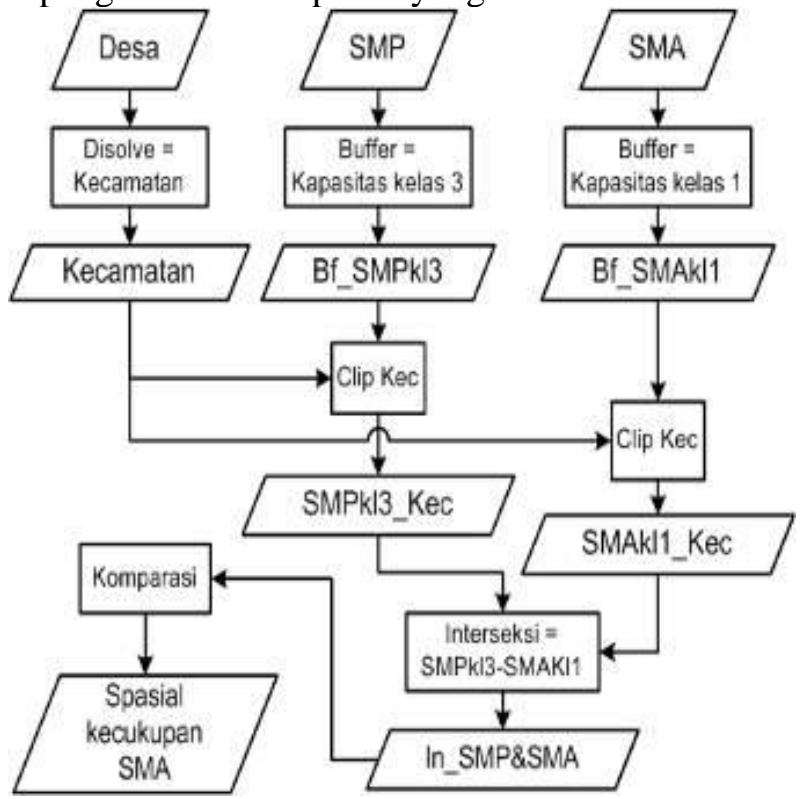

Gambar 2. Model Pemoresan Data Spasial untuk Verifikasi Parameter [11]

Hasil verifikasi yang valid adalah sebagai produk parameter yang akan digunakan untuk keperluan proses buffer data spasial SMA. Jika diperoleh tidak valid, maka dilakukan peninjauan ulang dan perbaikan parameter. Proses perbaikan tersebut sampai dihasilkan parameter yang valid. Produk akhir secara data spasial adalah data/informasi spasial hasil analisa spasial komposisi SMA terhadap keberadaan SMP untuk keperluan identifikasi kecukupan fasilitas SMA dalam menampung lulusan SMP.

\section{Hasil dan Pembahasan}

Zonasi terhadap obyek suatu sekolah (SMA) secara dasar dihasilkan oleh proses data spasial berupa buffer. Buffer dapat dibentuk dengan menyertakan nilai satuan jarak guna mendapatkan luasan wilayah di sekitar obyek spasial [10].

\subsection{Hasil}

Produk yang diperoleh sebagai hasil diperoleh berdasar melaksanakan metodologi adalah data spasial dan parameter buffer untuk pemrosesan data spasial pembentukan wilayah zonasi SMA. Gambar 3 merupakan hasil pemetaan lokasi SMP beserta hasil proses buffer di seputar lokasi SMP berada. 


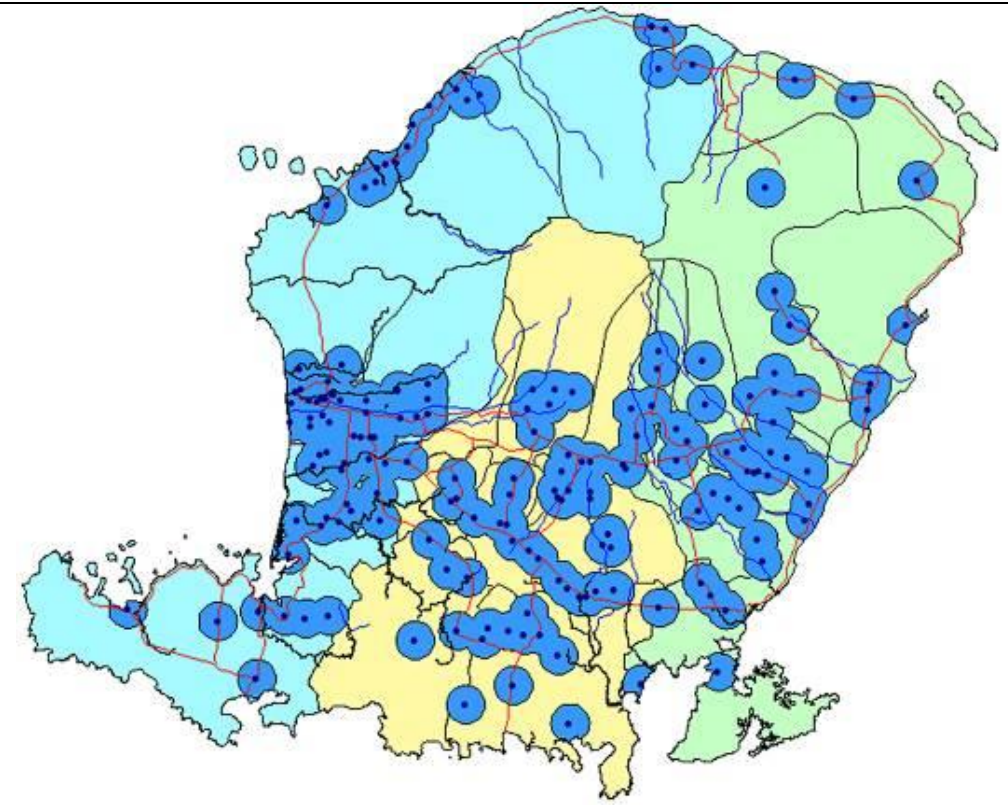

Gambar 3. Pemetaan Lokasi SMP dan buffer wilayah sekitar SMP di pulau Lombok

Bagian utama data spasial dalam bahasan ini adalah pemuatan lokasi (fasilitas) sekolah menengah (SMA). Pada Gambar 4 dipresentasikan lokasi SMA di pulau Lmbok beserta hasil buffer SMA untuk indikasi wilayah zonasi tiap-tiap sekolah. Hasil awal yang diperoleh berdasar Gambar 4 adalah terdapat beberapa kondisi yang menjadi keragaman keadaan berdasar kebijakan zonasi.

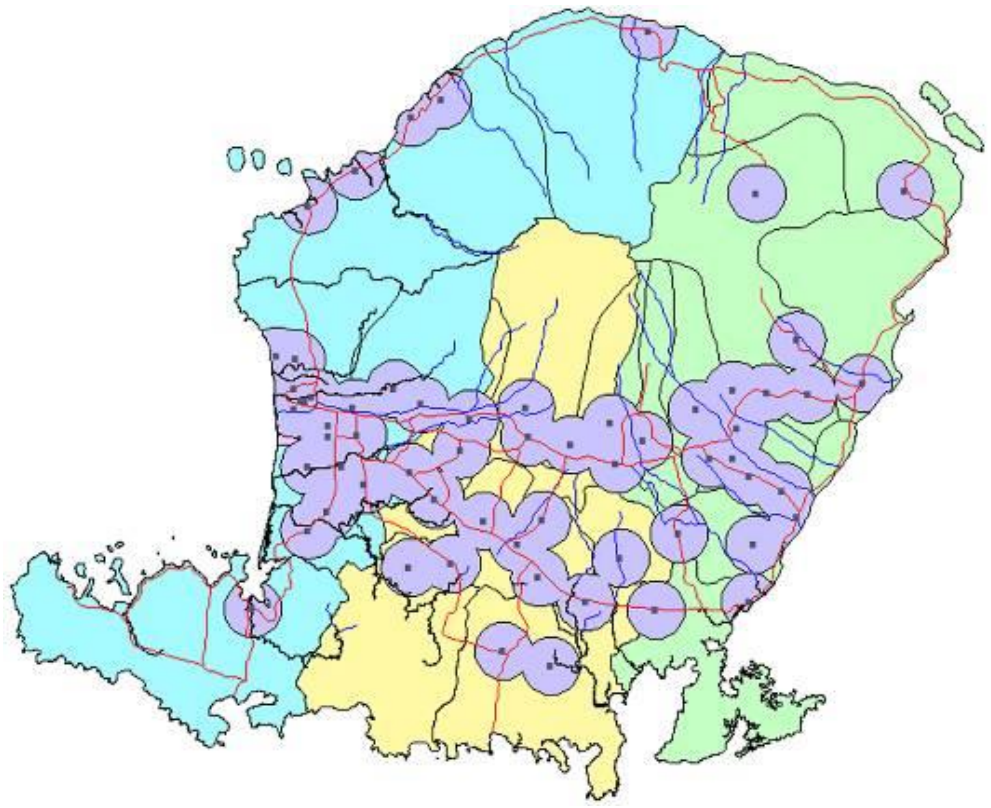

Gambar 4. Pemetaan Lokasi SMA dan buffer wilayah sekitar SMP di pulau Lombok

Memperhatikan hasil proses buffer pada Gambar 4 dapat diketahi, terdapat area yang memiliki kesenjangan dan tidak terjangkau oleh cakupan area buffer. Ragam kedua adalah terdapat area yang memiliki sentuhan antara hasil buffer SMA yang satu dengan SMA yang lainnya. Ragam ketiga adalah area hasil proses buffer didapati overlap berdasar area antar sekolahnya.

Parameter yang dihasilkan berdasar proses penyusnan dan pengolahan data spasial dapat ditemukan. Untuk mendapatkan nilai satuan jarak untuk keperluan proses buffer tidak dapat hanya berdasar ukuran jarak lokasi. Terdapat faktor lain yang tidak dapat diabaikan, antara lain, 
tingkat kepadatan penduduk, kepadatan jumlah calon (potensi) peserta didik yang berada di sekitar SMA. Persamaan (1) adalah parameter yang diperoleh dan telah terverifikasi valid untuk mendapatkan nilai jarak pada proses buffer.

$$
\text { bufV }=\frac{\text { anak usia sekolah } / \mathrm{km}^{2}}{\text { Kepadatan penduduk } / \mathrm{km}^{2}} \mathrm{x} \text { jarak jangkauan sekolah (m) }
$$

Nilai yang dihasilkan oleh persamaan (1) dipergunakan untuk mengisi nilai jarak pada proses buffer data spasial lokasi SMA. Berdasar proses verifikasi menggunakan proses pada gambar 2 dan persamaa (1), didapat 1 dari 10 kali proses mendapatkan hasil tidak terverifikasi. Proses verifikasi dilakukan sebanyak $10 \mathrm{kali}$. Sampling dilakukan terhadap 10 sekolah, diperoleh 9 sekolah memenuhi kondisi yang beresuaian, sebagaimana ditunjukkan pada Tabel 1.

\begin{tabular}{cccc}
\multicolumn{4}{c}{ Tabel 1. Verifikasi Zonasi Menggunakan Parameter } \\
\hline Sekolah & Zona di lapangan & Proses Buffer & Kesesuaian \\
\hline SMA 1 Mataram & 4 & 4.1 & Sesuai \\
SMA 2 Mataram & 5 & 5.05 & Sesuai \\
SMA 5 Mataram & 5 & 5 & Sesuai \\
SMA 1 Gerung & 7 & 9 & Ada simpangan \\
SMA 1 Lingsar & 8 & 8 & Sesuai \\
SMA 1 Narmada & 8 & 7.9 & Sesuai \\
SMA 1 Kopang & 8 & 8 & Sesuai \\
SMA 1 Masbagik & 9 & 9 & Sesuai \\
SMA 1 Jonggat & 9 & 8.9 & Sesuai \\
SMA 1 Praya & 5 & 5 & Sesuai \\
\hline
\end{tabular}

Secara tampilan spasial dapat diperhatikan pada Gambar 5, yang mengilustrasikan kondisi secara spasial (vektor). Ilustrasi tersebut dapat memberikan informasi spasial yang mengindikasikan kawasan zona yang dicapai.

\subsection{Pembahasan}

Capaian hasil telah diperoleh, yaitu parameter proses buffer pengolahan data spasial untuk identifikasi zonasi penerimaan siswa SMA terhadap lulusan SMP di pulau Lombok. Parameter untuk menghasilkan nilai jarak pada proses buffer data spasial berdasar persamaan (1). Implementasi dasar parameter telah diperoleh sesua dengan gambar 4, terbentuknya area zonasi di seputar lokasi fasilitas SMA berada. Sebesar 90\% proses buffer dapat menghasilkan pola zonasi SMA yang diinginkan. Sehingga dapat mengidentifikasi area cakupan untuk keperluan pelaksanaan Penerimaan Peserta Didik Baru.

Berdasarkan Gambar 4, diperoleh ilustrasi tentang pola zonasi penerimaan siswa baru SMA. Pemrosesan data spasial yang ihasilkan pada gambar 4 merupakan hasil buffering lokasi SMA berada. Sesuai ilustrasi pada gambar 4, diperoleh tiga kondisi dasar area zonasi yang berdasarkan nilai jarak yang dihasilkan persamaan (1). Tiga kondisi dasar tersebut adalah diperolehnya area yang berada diluar zonasi, area yang berada diantara dua atau lebih zonasi dan area yang berada di dalam dua area zonasi atau lebih. Ketiga kondisi dasar zonasi tersebut ditunjukkan pada Gambar 5. 


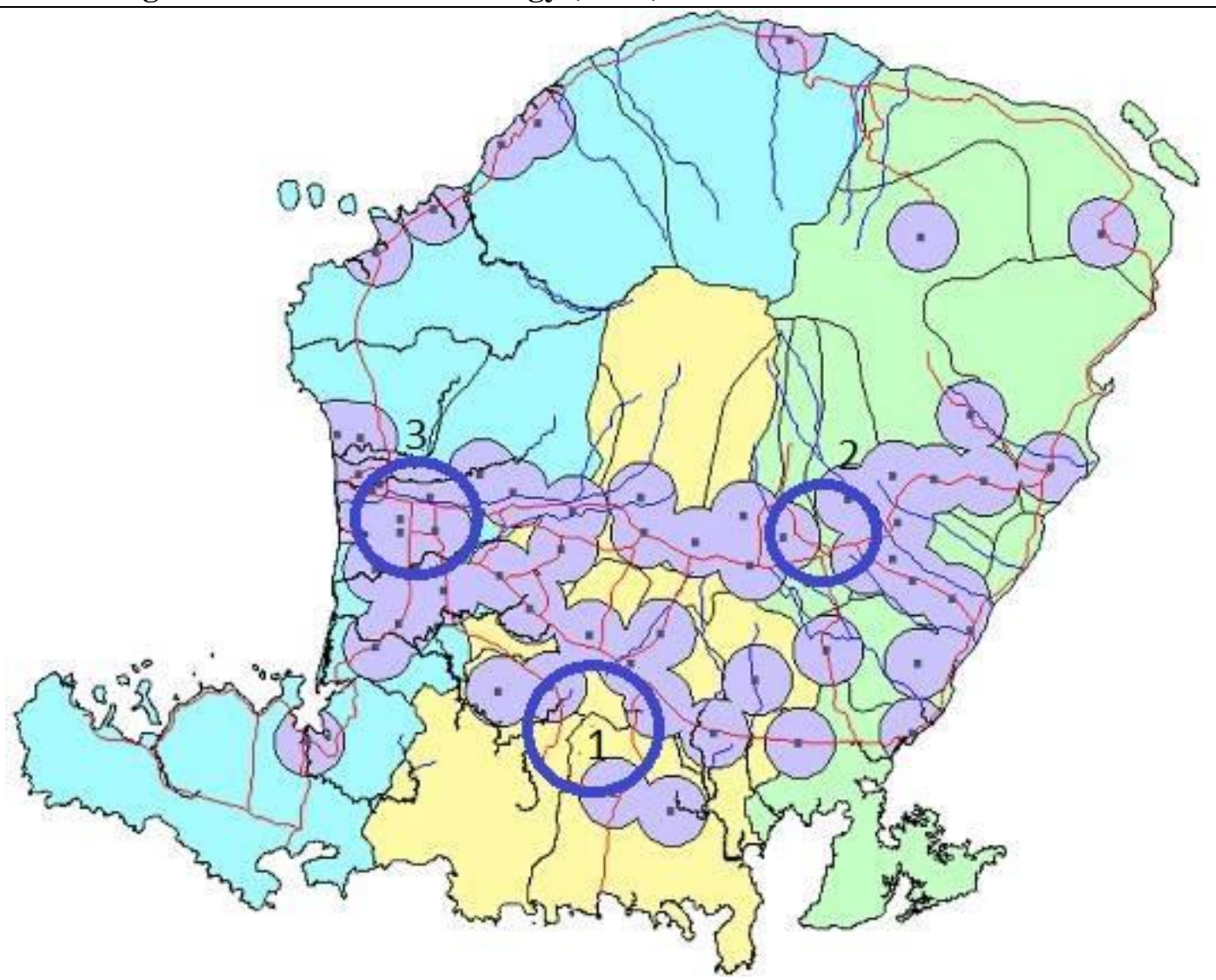

Gambar 5. Tiga Kondisi Dasar Area Berdasar Proses Buffer untuk zonasi

Gambar 4 dan 5 pada dasarnya adalah hasil proses buffer data spasial yang diolah untuk mendapatkan identifikasi area zonasi SMA untuk keperluan penerimaan siswa baru. Pada gambar 5 terdapat tanda lingkaran dengan inisial nomor 1, menunjukkan area yang berada diluar zonasi. Tanda lingkaran berinisial 2 adalah area yang berada diantara dua atau lebih zonasi. Tanda lingkaran berinisial 3 adalah area yang berada di dalam dua area zonasi atau lebih.

Memperhatikan isi peraturan menteri, tentang area dengan kondisi berinisial 1 dan 2, maka pihak Dinas Pendidikan wilayah setempat bertanggung jawab atas distribusi calon siswa yang berada di luar area zonasi [7]. Memperhatikan hal tersebut maka perlu dilakukan identifikasi berdasar zonasi lulusan SMP terhadap zonasi penerimaan siswa baru SMA. Gambar 6 adalah hasil penglahan data spasial yang merupakan perpaduan antara proses data spasial berdasar SMP dan proses data spasial berdasar SMA, sesuai dengan model pengolahan data pada gambar 2. Perpaduan kedua data spasial zonasi SMP dan zonasi SMA akan dapat digunakan untuk identifikasi maupun analisa terhadap kebutuhan pendistribusian siswa lulusan SMP agar dapat masuk ke sekolah menengah. 


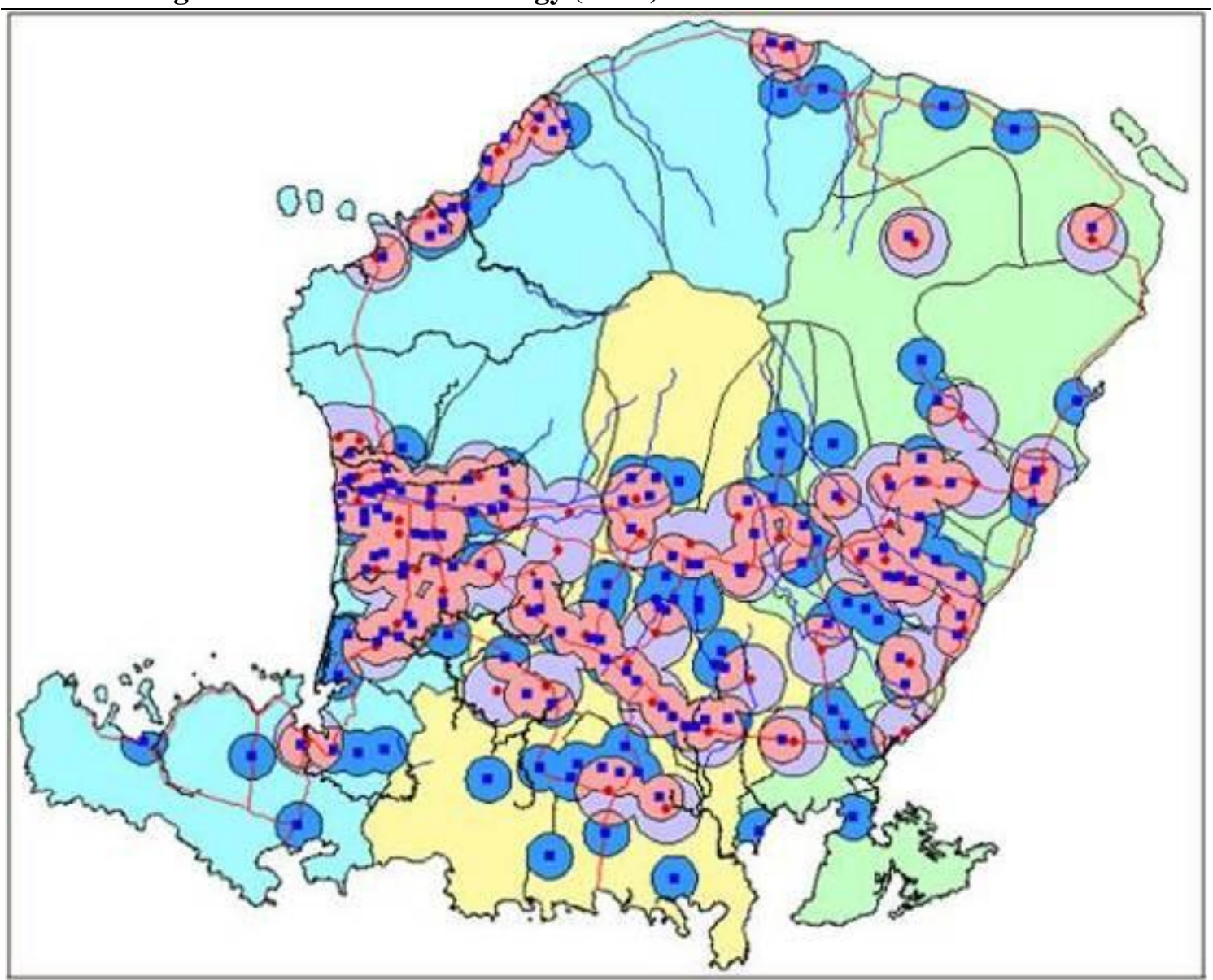

Gambar 6. Data Spasial Zonasi Fasilitas Pendidikan Jenjang SMP di pulau Lombok

Pada Gambar 6 tampak jelas hasil pembentukan zonasi SMP dan SMA. Berdasar informasi spasial pada Gambar 6, dapat diketahui wilayah yang masuk pada zonasi SMA, sampai dengan yang jauh diluar jangkauan.

\section{Kesimpulan}

Parameter yang diperoleh dalam formulasi dapat dipergunakan untuk mendapatkan nilai jarak yang diperlukan pada proses buffer data spasial untuk mendapatkan area zonasi. Data spasial hasil proses buffer untuk mendapatkan wilayah zonasi dapat diperoleh. Area zonasi SMA dapat diperoleh melalui proses buffer yang nilainya diperoleh berdasar parameter yang telah disusun, sebesar $90 \%$ dapat tercapai. Dengan demikian parameterisasi proses buffer pada pengoulahan data spasial untuk identifikasi zonasi penerimaan siswa SMA terhadap lulusan SMP di pulau Lombok, dapat dicapai. Pengembangan lebih lanjut, parameter proses buffer data spasial ini dapat diaplikasikan untuk keperluan perencanaan program pembangunan. Pelengkapan atribut data vector dan singlronisasi dengan data spasial pendidikan di tiap Pemerintah Daerah, dapat diberdayakan untuk menyusun perencanaan pembangunan dan program kerja Pemerintah Daerah.

\section{Ucapan Terima Kasih}

Terima kasih disampaikan kepada DP2M yang pernah memfasilitasi penelitian pendahuluan melalui program PDM 2006 dan PHB tahun 2012-2013. Terima kasih juga disampaikan kepada tim INC NTB yang membantu dalam riset Mandiri di tahun 2020. Terima kasih juga pada tim redaksi dan editor BITe yang telah bersedia menunggu artikel ini siap. 


\section{Referensi}

[1] S. N. R. Indonesia, Undang-undang Republik Indonesia Nomor 20 Tahun 2003 Tentang Sistem Pendidikan Nasional. Lembar Negara Republik Indonesia Nomor 78, Sekretariat Negara Republik Indonesia, 2003, pp. 1689-1699.

[2] R. Arini, "Kemendikbud Canangkan Program Wajib Belajar 12 Tahun," DetikNews, 2012. http://news.detik.com/read/2012/03/06/211045/1859667/10/kemendikbudcanangkan-program-wajib-belajar-12-tahun (accessed Sep. 01, 2012).

[3] Adminsidiknas, Sekolah Menengah Atas”, Kementrian Pendidikan dan Kebudayaan Republik Indonesia. Kementrian Pendidikan Nasional, 2012.

[4] A. Pribadi, "Perencanaan Pengolahan Data Spasial Untuk Menduga Kecukupan Daya Tampung Sekolah Menengah Atas Berdasar Lulusan Sekolah Menengah Pertama," KNSI 2013, 2013.

[5] BKLN, “Analisa Data Pendidikan 2007 / 2008," Departemen Pendidikan Nasional Nusa Tenggara Barat. http://pkln.diknas.go.id/download/analisis/NTB.pdf. (accessed Apr. 26, 2009).

[6] Biro Hukum dan Organisasi Kementrian Pendidikan dan Kebudayaan, "Peraturan Menteri Pendidikan dan Kebudayaan Republik Indonesia Nomor 14 Tahun 2018, Tentang PPDB pada TK, SD, SMP, SMA, SMK, atau Bentuk Lain Yang Sederajat," Ber. Negara RI Tahun 2018 Nomor 605, Direktur Jenderal Peratur. PerundangUndangan, Kementrian Huk. dan Hak Asasi Mns. RI, [Online]. Available: https://jdih.kemdikbud.go.id/arsip/Permendikbud_Tahun2018_Nomor14.pdf.

[7] P. web Kemdikbud, "Sistem Zonasi Mempercepat Pemerataan di Sektor Pendidikan," BKLM Kementrian Pendidikan dan Kebudayaan. https://www.kemdikbud.go.id/main/blog/2018/06/kemen dikbud-sistem-zonasimempercepat-pemerataan-di-sektor-pendidikan. (accessed Dec. 09, 2019).

[8] E. J. S. De Bay, Rolf A., Ricard A. Knippers, Yuxian Sun, Martin C. Ellis, Menno-Jan Kraak, Michael J. C. ewir, Yola Georgiadou, Mustafa M. Radwan, Cees J. van Westen, Wolfgang Kainz, Principles of Geographic Information Systems: An introductory textbook. The Netherlands, Enschede: The International Institute for Aerospace Survey and Earth Science, 2000.

[9] K. Chang, Introduction to Geographic Information System. New York: Mc Graw Hill, 2002.

[10] A. Pribadi, "Rancangan Atribut Data Spasial Untuk Satuan kerja Perangkat Daerah (Pendidikan) Pada SIGDa Kabupaten Lombo Barat," Matrik, vol. Vol. 15, no. No. 2, 2015.

[11] A. Pribadi, "Model Data Spasial Dan Model Pemrosesan Data Spasial Pendugaan Daya Tampung SMA Teradap Lukusan SMP." . 

ISSN: 2685-4066 